\title{
Metaphoric Symbolism In Printmaking as a Means of INTERPRETIVE EXPRESSION IN ART BY NORMATIVE AND EMOTIONALLY DISORDERED INDIVIDUALS
}

\author{
By \\ Ph.D. Faridah sh Mohammad \\ PH.D. Karen E. Greenberg \\ Associate Professor \\ College of Basic Education \\ Psychotherapy \& Forensic \\ Social Work \\ Public Authority for Applied \\ State of Virginia \\ Education and Training \\ U.S.A. \\ State of Kuwait
}

\section{Research Joupnal Specific Education}

Faculty of Specific Education

Mansoura University

ISSUE NO. 27, OCTOBER. 2012

$$
\text { مجلة بحوث التزبية النوعية ـ جامعة المنصورة }
$$




\title{
Metaphoric Symbolism in Printmaking as a Means of INTERPRETIVE EXPRESSION IN ART BY NORMATIVE AND EMOTIONALLY DISORDERED INDIVIDUALS
}

\author{
Ph.D. Faridah sh Mohammad
}

Ph.D. Karen E. Greenberg **

\section{Abstract}

Printmaking presents a unique aspect for psychotherapists, it allows for the production of multiples and interaction between the product and the client. It reinforces the nature of printmaking which is experimental, innovative, and explorative. The premise of the research was to explore how culture affects interpretation of the printmaking. The researcher utilized mono-print images from Kuwait by Kuwaiti students at $\mathrm{Ku}$ to test the theory of art become a universal form of creativity that enhance everyone to look at it and interpreted in an individual way. To explore the influence of culture on the interpretation of art printmaking, the researcher divided the sample into two groups of American citizen: 1-normative group, 2-emotional disordered group in order to let psychotherapist become more familiar with this medium and become a visible aid in psychotherapist area.

\footnotetext{
Associate Professor College of Basic Education Public Authority for Applied Education and Training State of Kuwait

"* Psychotherapy \& Forensic Social Work State of Virginia U.S.A.
} 


\section{Metaphoric Symbolism in Printmaking as a Means of INTERPRETIVE EXPRESSION IN ART BY NORMATIVE AND EMOTIONALLY DISORDERED INOIVIDUALS}

\section{Ph.D. Faridah sh Mohammad"}

Ph.D. Karen E. Greenberg ${ }^{* *}$

\section{Introduction}

The print is unique among artistic media. The wide range of materials and diversity of techniques associated with printmaking make it particularly flexible and resourceful medium, offering the artist many varied possibilities for experiment and expression. This flexibility accommodates both the serious artist and professional-satisfying. Results can be achieved quite quickly, using different techniques. No matter how complicated the process, all printing involves two surfaces: one bearing the image and the other upon which the image is impressed (Saff, 1980, 37).

The modern print is a product of constantly evolving mechanical processes, a result of a technological inventiveness which has stimulated the artist's imagination and developed his skills as a printmaker. Printmaking is a medium of pure artistic expression. The factors involved the invention of mass visual communication. The industrial revolution and the everincreasing social mobility towards the end of nineteenth century stimulated the search for knowledge and brought culture and art to many more people. The print became the most popular medium for the acquisition of factual knowledge and cultural images in an easily accessible form.

As more artists took to the medium, printmaking grew rapidly; as a result, an endless variety of new techniques and materials emerged. Working in an atmosphere of fast-developing technologies, artists created increasingly complex works. These works lent themselves to an obsession with technical invention for its own sake. Printmaking as an original art form rapidly deteriorated into a process of reproduction. (Ibid, 1980, 345)

\footnotetext{
Associate Professor College of Basic Education Public Authority for Applied Education and Training State of Kuwait

** Psychotherapy \& Forensic Social Work State of Virginia U.S.A.
} 
To practice printmaking under today's circumstances requires a long apprenticeship and a host of materials and equipment. When creating an image, it involves infinite expression. So, it's value to try explore this concept in the process of building an image which should take in terms of materials, tools and machines, a total transformation, therefore printmaking is divided into two major categories: process and materials, these are the results of artistic expression of an image. (Ibid, 1980, 351)

The first author has recently joined George Mason University at AVT (Art Visual Technology) department to conduct a research paper on mix media specifically in printmaking. As a result, the researcher thought about incorporating cultural influences of the US in a research paper. The premise of the research was to explore if or how cultures affects interpretation of the printmaking. The researcher utilized prints designed from Kuwait by Kuwaiti students at Kuwait University to test the theory of art become a universal form of creativity that enhances everyone to look at it and interpreted in an individual way. To further explore the influence of culture on the interpretation of art, the researcher divided the sample into two groups of Americans: 1-normative group, 2-and the other individual with emotional disordered. In exploring this concept, the hope is that psychotherapist will become more familiar with this medium and it will become a visible aid in psychotherapeutic areas.

Art had been proven to be an important aid in the treatment of relationship problems in psychotherapy. The use of art, combined with psychotherapy is gaining wide spread popularity and is being used more commonly (White,2002,35). Client's can express their feeling more easily through art. Art work is useful for processing strong feelings, clarifying confused feelings and sometimes artistic creations reveal facets of personality not easily accessible through verbal psychotherapy. Important diagnostic indications may be discussed projective techniques (Malchiodi,2007,61). Symbolic content and the formal characteristics of the work constitute a source of information uniquely available through the visual arts. These visual arts could be described as sequential and mechanical, gestalt, from the German word for whole. Whole in art consists 
of formal elements. These formal elements could be defined as point, line, shape, texture, space (Jackson,2008,67).

\section{Gestalt Theory}

The study used Gestalt theory to improve the quality of client's ability to learn, through experience. Gestalt psychology proposes that the brain is holistic with self- organizing tendencies. Due to these supposed innate abilities, the brain is capable of organizing and structuring individual elements, shapes, or forms into a coherent, organized whole. Although the individual elements may contain some meaning, the coherent whole will have a greater meaning than the sum of the parts. This satisfies the human brains need to find, or impose, meaning to a situation. As such, there are links between the perceptual qualities of gestalt and the aesthetic and compositional concerns of art and design (Jackson, 2008, 66).

Gestalt, as opposed to behaviorism, allowed the scope and opportunity to explore a more holistic and interrelated contextual allied learning experience. In the productive thinking, the client learns to explore the problem and define it. This transfer of external stimuli into internal process contributes to an informed understanding and a growing awareness of the structure of the problem (Ibid, 2008, 67).

\section{The Problem}

Printmaking presents a unique aspect for psycho- therapists. It allows for the production of multiples and the interaction between the product and the client. It reinforces the nature of printmaking which is experimental, innovative, and explorative (Saff,1980,39).

Printmaking comes through the search for a meaning of expressing one's idea. Trying to explore the development of the image which must take shape in terms of materials, tools, and equipment, the result will be the image that has been produced in the process that has been totally transformed. The image forms as the dynamic expression of its environment- the interaction of all the materials, tools, processes and the artist.

Psychotherapy is one of the fields that have been used by printmaking. Psycho therapy uses different types of art for use in therapeutic, 
occupational therapy or educational settings. However, printmaking had not been explored due to its association with expensive and imposing equipment and complicated processes. That's what led the first author to incorporate this type of art with the coordination of second author who acts as a psychotherapist on two groups: normative and emotional disordered. The emotional and normative groups were diagnosed and identified by second author on p.10 and were interviewed by second author to fulfill the condition of this paper in applying gestalt law theory in interpreting the art work and cultural impact.

\section{Objectives}

1- To utilize Gestalt theory as a method and define the cultural affects individual's interpretations of art.

2- To emphasize cultural impact effects on both groups (normative \& emotional groups).

3- To highlight the assumption that the cultural impact will define the interpretations.

\section{Research questions}

1. How do people with emotional problem, they fall under the Gestalt law theory when they are interpreting the art work.

2. How does Gestalt theory effect the cultural perception of the normative group.

3. How if any sensory limitations were found in either group

\section{Limitation}

- The study though based on a limited sample of six patients and six normative individual both male and female subjects ranging in ages from 16-55. The subjects were divided into two groups; a normative one and the second group displaying emotional disordered.

- This study will be limited on mono type printmaking technique.

- This study randomly selected 6 prints abstract art works that had been produced at Kuwait University, State of Kuwait.

\section{Need for the study}

Printmaking is indirect and most of the time the image is in reverses; possessing both challenge and opportunity. This complex and multi-stepped 
art making process has a distinct advantage for art therapists because it produces a distance from art work that can be beneficial for some clients. All relief, intaglio and mono type printing creates an image in reverse. The distance of the finished print will give clients a chance to slow down, engage in the therapeutic process and even control violent imagery. There is a need to open another approach for psychotherapy in order to sustain personal emotion by using variety of artistic expression through printmaking mono-type. Printmaking reduces resistance because of its mechanics and unpredictability and it's a new experience for the client to rethink old images. Printmaking allows clients who are afraid of their own pathology or embarrassed about their deficits to participate in psychotherapy.

\section{Definition of terms:}

Print: is an image produced on paper or another material by placing it in contact with an inked block, plate, collage or stone and applying pressure; or pressing ink onto a sheet of paper through a stencil. (Saff \& Sacilatto, 1980, 344)

Mono type: a print made by transferring the paper to a wet painting made on glass (or stone or metal) only a single print can be made. (Ibid, 1980, 342)

Psychotherapy: the science dealing with mind \& mental processes, feelings, desires, etc. (Webster Dictionary, 1983)

Adjustment disorder: with mixed anxiety and depressed mood: when the predominant manifestation is a combination of depression and anxiety. (Diagnostic Criteria from DSM-IV).

\section{Related literature}

\section{Psychology and its relation to art}

At the beginning of this century the scientific community investigated all aspects of perceiving gained momentum. For example, as soon as the first mark is made on a blank sheet of paper, it's altered by the eye. We no longer see a flat piece of paper. Our past experiences, our expectations, and the structure of the brain itself filter the information. This visual illusion created through this process is part of perception. (Arnheim, 1969, 37). Perception is an intrinsic part of the psychology of the individual. As Anna 
Berliner explains "seeing depends not only upon the environment but also upon the state of the person". Each person's perceptions are intimately linked to such factors as action, purpose, and expectancy, as well as to the total environment. In 1912, some of psychology schools were established and one of these schools was Gestalt psychology. Their main exponents were Max Wertheimer and his assistants Kurt Koffka and Wolfgang Kohler. They believed that brain interprets and groups the image on a flat surface.

The Gestalt investigated how we see and organize visual information into a meaningful whole. The conviction developed that the whole is more than the sum of its parts. This whole cannot be perceived by a simple addition of isolated parts. Each part is influenced by those around it (Avntson, 2003, 80).

The crucial findings of the Gestalt school as they apply to design were formulated into a series of perceptual laws:

1. The first is the law of equilibrium, and is based on the innate tendency of the cognitive process of the brain toward simplicity and equilibrium and cohesion. This law involves the universal striving of all physical organisms for perfect balance.

2. The second law, the law of closure, involves another aspect of perceptual structuring emphasized by the Gestaltists. Closed areas are perceived as more stable, so there is a natural tendency to close gaps have or complete figuration that have been left open.

3. The third law deals with the organization of visual perception, which is such that a curved line is likely to appear as part of a circle and straight line to continue as a straight line even though alternatives are possible. This factor is known as the law of good continuation.

4. The fourth law is the law of similarity and requires that "visual units which resemble each other in shape, size, color, and direction will be seen together as a homogeneous". This law is based on the tendency of the eye to organize visual stimuli into ordered pattern, a tendency which is closely allied with the fifth law of proximity.

5. The fifth law is the law of proximity which is "in visual perception what is closet together tends to unite". Images of objects that are close 
to one another form groups and are seen against an empty space. This tie in figure is dependent on the character of the surround surface in the field, even if this includes other figure. By definition, figures have a specific shape, whereas the back ground is shapeless (Clibborn , 1980, 139 ).

\section{Variables of color perception}

Color sensations occur in the responses of our perceptual apparatus. Wavelengths affecting our perception of a color: size of color area, the lighting under which it is seen, and the surface texture of the object from which it is reflected. In addition to size, surroundings, and lighting, the color we perceive depends, on pigments, and on the characteristics of the surface from which it is reflected. A shiny surface will reflect more light and thus seem lighter; a rough or porous surface will absorb more light and therefore appear darker. A shiny surface will also reflect the colors around it. Such glossy surface also develops a direct range of values from highlights to dark values, as in the many reflected yellows that derive from the solid yellow of the surroundings (Clibborn, 1980, 21).

\section{Psychological effect of color}

It's universally accepted that colors affect us emotionally. Color can therefore be used to express emotions and even to evoke them. However we must be aware that any slight differences in colors can produce quite different effects. There are many factors that cause effect: Physiological, personal, emotional and color symbolism.

\section{Physiological Effect}

In chromo therapy, people are bathed with color light, placed on colored environments, though to stimulate particular glands. This form of treatment dates back to ancient Egyptian, Chinese, and Indians. Red is believed to stimulate physical and mental energies, yellow to stimulate the nerves, orange to stimulate the solar plexus and revitalize the lungs, blue to sooth and heal organic disabilities, green to exercise a calming influence and heal disorders such as colds, hay fever, and liver problems, and indigo to counteract skin problems and fever (Zelanski, 1989, 30). 


\section{Personal Effect}

People with certain mental illness-particularly schizophrenia- show a preference for non-chromatic, neutral color (white, black, brown, gray), while normal people and manic depressive tend to prefer chromatic hue. Extroverts tend to prefer warm hues: introverts like cool hues. However, people may be drawn toward color representing qualities they lack, for balance. Red, for instance, is usually the preference of vibrant, outgoing, impulsive people, but timid people may also be drawn in it. Those who are feeling frustrated or angry may be repelled by red (Ibid, 1989, 32).

These are some of the factors that the color has on a person:

1. The various symptoms and signs of illness known to be affected by the color.

2. The specific physiological effects desired and known to be caused by the color.

3. The individual body parts and organs known to be influenced by the color.

4. Each color of light vibrated at a different frequency. The color vibrations reach the patient's etheric body and "energize" it to start vibrating and do what it should be doing.

5. Color is basic to any system of healing. Color is nature's own curative measures, and it functions under certain basic postulation.

(walker,1991,85)

The following are examples of function of color on organism and on person:

Red: rays produce heat and vitalize and energize the liver, the muscular system, and the left cerebral hemisphere. As a muscle relaxant for contractures, red's counter- irritant effects are excellent for therapeutic purpose, the muscular system, and the left cerebral hemisphere.

Yellow: activate the motor nerves and generates energy for the muscles, it tends to both stimulate function and repair damage. Nerve building takes place in the presence of yellow. It lifts despondency and suggests joy, gaiety, intellect, perception, and merriment. 
Orange: has an antispasmodic effect on muscle cramps, aids calcium metabolism, acts as an emetic and increases the pulse rate.

Green: is cooling, smoothing, and calming both physically and mentally. It relieves tension, lower blood pressure, acts as a hypnotic upon the sympathetic nervous system, dilates the capillaries, and produce a sense of warmth. Green rays help stabilize the emotions and stimulate the pituitary.

Blue: is the balancing and harmonizing color that returns the blood stream to normal. It reduces nervous excitements, is astringent, and can be absorbed from the environment during meditation and spiritual expansion. It relaxes the mind. Moreover, it's the color of truth, devotion, calmness, sincerity, intuition, and higher mental faculties.

Indigo: is electric, cooling, and astringent. It promotes muscular tonicity, respiratory depression and control forehead chakra and influence vision, hearing, and smell on the physical, emotion, and spiritual planes.

Violet: is calming in cases of mental illness. It controls irritability, reduces hunger, builds leucocytes, and maintains ionic balance especially of potassium and sodium (Ibid, 1991,88).

So, colors consider the most absorbable and easiest elements for utilization by the body because its vibrations are so easily accepted by human tissues. As a result, color rays absorbed through the skin and affect all the glands, blood cells, and chemicals in the body: the purer the color, the more penetrating the rays and the faster the body's reaction (Ibid,1991,95).

\section{Emotional effects}

The actual effect of a specific color in an art work depends partly on its holistic environment viewing blue as a larger area is quite different from seeing a small area of blue in larger color content. For many of us, the emotional effects of art may be difficult to articulate because of the following factors: culture, religious, location, interaction within the area of exposure. 


\section{Color Symbolism}

Colors are influenced by the color association from our specific cultures. In western industrial cultures, black is associated with death, west India uses bright colors to commemorate deaths, China used color white for morning, red is associated with vigorous life in many culture. Highly saturated reds are often linked with sexuality or fertility, while light values of red-pinks- may be used to express affection and sweetness. (Zelanski \& Fisher, 1989, 31)

\section{Symbol}

A symbol is something that conveys to the mind an image of something other than itself. Symbols have always been treasured as a means of releasing. They renew energy from consciousness, by gradually integrating conscious with un- conscious content in the psyche; they affect the quality of your personal life, as well as bringing value and meaning to it (Roukes,1988,121)

When looking at a symbol, it has three aspects: it has a form (how it appears), it has objective definition (is it cross or dagger), and finally it has significance (meaning in the particular context in which it appears). Symbol also has several advantages including: 1.original construction, 2. Simple gestalt resulting in quick recognition, 3. A strong association that "colors" the symbol's interpretation. Symbols can also be examined in light of semiotics, where an image takes on a culturally accepted meaning that goes beyond its merely recognizable shapes. Therefore, when looking at a symbol, it is important to remember that they are a product of symbolic mode of thought. It's a different way of communicating experience from the logical or numerical modes of experiences (Roukes, 1988, 105).

\section{The importance of the form and its status in the art work}

Form includes shape, size, color, and texture that occupies space, marks position, and indicates direction. A created form can be based on reality, recognizable- or abstract- un recognizable. A form might be created to convey a meaning or message, or could be merely decorative. Two dimensional forms consist of points, lines, or planes on a flat surface. Our visual experiences of the three-dimensional world influence our perception 
of two- dimensional forms. A shape against an empty background appears to be surrounded by a void. Volume and thickness can be added to a shape which can be rotated in space to exhibit different views (Wong, 1993, 138).

\section{Methodology:}

The methodology utilized was qualitative using a descriptive approach. The first researcher who is a professor of art at Kuwait University used six abstract mono-print which had been printed by Kuwaiti students at Kuwait University at printmaking course of fall, 2007 will be analyzes in terms of color, form, and interpretations. The first researcher provided set of questionnaire (see page 34) were used by second researcher, who is a psychotherapy and forensic social work, with the two American groups to test the research questions. (See appendix 1) The categories will be the two group's response to the art work, where the last part will be the first researcher response based on the premises of Gestalt theory. So, the first researcher has summed up the answers of the two groups because of their similar responses.

\section{A Emotional disorder Group}

\begin{tabular}{|l|l|l||}
\hline \multicolumn{1}{|c|}{ Gender } & Age & \\
\hline \hline 1- male & 16 & Anxiety (300.9) \\
\hline 2- Female & 40 & Depression (300.4) \\
\hline 3- Male & 65 & PTSD * \\
\hline 4- Female & 50 & PTSD \\
\hline 5- Female & 41 & Anxiety (308.03) \\
\hline 6- Male & 45 & Adjustment disorder, anxiety emotional features (308.28) \\
\hline
\end{tabular}

* PTSD: Post Traumatic Stress Disorder (309.81).

\section{B Normative Group}

\begin{tabular}{||c|c|l||}
\hline Gender & Age & Diagnosis \\
\hline \hline 1- Female & 40 & Normative \\
\hline 2- Female & 50 & Normative \\
\hline 3- Male & 32 & Normative \\
\hline 4- Female & 59 & Normative \\
\hline 5- Male & 35 & Normative \\
\hline 6- Male & 38 & Normative \\
\hline
\end{tabular}




\section{Work \# 1}

Title: overcoming obstacles

Media: mono-print

Size: 8"x11"

Year: Fall, 2007

\begin{tabular}{|c|c|c|c|}
\hline $\begin{array}{c}\text { Groups } \\
\text { Categories } \\
\end{array}$ & Color & Form & Interpretation \\
\hline $\begin{array}{l}\text { Emotional } \\
\text { disordered }\end{array}$ & $\begin{array}{l}\text { Movement } \\
\text { from dark to } \\
\text { light-contrast } \\
\text { black and } \\
\text { white- sharp } \\
\text { line }\end{array}$ & $\begin{array}{l}\text { Sharp shapes- figure is } \\
\text { the sharpest form- } \\
\text { person- central cored- } \\
\text { contrast movement } \\
\text { comes from cored into } \\
\text { the center. }\end{array}$ & $\begin{array}{l}\text { Confused- conflict- scared- } \\
\text { positive vs negative- } \\
\text { internal vs external- moving } \\
\text { towards resolution negative } \\
\text { answer- unable to escape- } \\
\text { blew up- shape generate } \\
\text { pain- fear- unable to move } \\
\text { obstacles- over power the } \\
\text { person the person- fear- } \\
\text { confusion- uncertain- } \\
\text { anxiety. }\end{array}$ \\
\hline $\begin{array}{c}\text { First } \\
\text { Researcher } \\
\text { result }\end{array}$ & \multicolumn{3}{|c|}{$\begin{array}{l}\text { In this image, the form of figure was cleared and highlighted with black } \\
\text { and inner white space as Wong stated that figure form include shapes } \\
\text { that indicated directions. The figure visualizes whole because the } \\
\text { conviction developed that the whole is more than the sum of the parts. } \\
\text { This whole cannot be perceived by a simple addition of isolated parts. } \\
\text { Each part is influenced by the parts around it. Five responses of six had } \\
\text { noticed that there are sharp shapes, contrast form and color. The sharp } \\
\text { direction of the color from the center towards out had given the feeling } \\
\text { of pushing these shaped strongly and tried to resist these elements } \\
\text { which generate feeling of pain. This aspect dealt with the law of } \\
\text { continuation where the eyes followed the curve of an adjoining object } \\
\text { and goes out in different direction. Four responses of six saw the } \\
\text { appearance of trapped figure in a box is trying to use his arms to push } \\
\text { away the sides had given the feeling of unable to escape and involved } \\
\text { in proximity law where the closer two visual elements are, the more } \\
\text { likely we will see them as a group. Contrast of black and white caused } \\
\text { the feeling of questioning the status of this person. Feeling good or } \\
\text { bad, positive and negative resulted conflict, fear, and anxiety. This is } \\
\text { the law of continuation where the eyes followed the contrast image in } \\
\text { order to question the status of the figure. }\end{array}$} \\
\hline
\end{tabular}




\begin{tabular}{|c|c|c|c|}
\hline $\begin{array}{l}\text { Normative } \\
\text { groups }\end{array}$ & $\begin{array}{l}\text { Dark color } \\
\text { down- light } \\
\text { towards up- } \\
\text { contrast- dark } \\
\text { flames }\end{array}$ & $\begin{array}{l}\text { Stalagmites- rock formation- } \\
\text { cave- body \& head \& legs- } \\
\text { dismembered person- jagged } \\
\text { pieces- vulture- rocky cliff- } \\
\text { landscape- curves- spiral } \\
\text { shapes- triangles- heavy line } \\
\text { brush work. }\end{array}$ & $\begin{array}{l}\text { depressing- flowing } \\
\text { of line- underground } \\
\text { cave- mother nature- } \\
\text { searching for path- } \\
\text { truth- struggle- } \\
\text { walking through } \\
\text { dark area then sun } \\
\text { light comes towards } \\
\text { top- release- forest } \\
\text { view because of the } \\
\text { shapes- shining } \\
\text { flash light- ribbon } \\
\text { on the tree ties } \\
\text { between the tree and } \\
\text { stalagmites- } \\
\text { landscape- reflective }\end{array}$ \\
\hline $\begin{array}{c}\text { First } \\
\text { Researcher } \\
\text { result }\end{array}$ & \multicolumn{3}{|c|}{$\begin{array}{l}\text { In this image, the form of landscape (cave) was noticed through rock } \\
\text { formation, stalagmites, and rocky cliff as Wong indicated that form } \\
\text { created to convey meaning or message. This aspect involved with the } \\
\text { law of similarity, where we group the similar forms of rock and they } \\
\text { occur in similar shape, size, and color. The flowing of line elements } \\
\text { starting from bottom to up suggest the law of continuation where the } \\
\text { eye carried smooth line of an adjoining object which gives the view of } \\
\text { walking through dark area then heading sun light where approaching } \\
\text { towards pointed element up the image. The image of Mother Nature } \\
\text { provokes the aspect of looking, searching for, wondering of directions } \\
\text { but though is neutral. }\end{array}$} \\
\hline
\end{tabular}




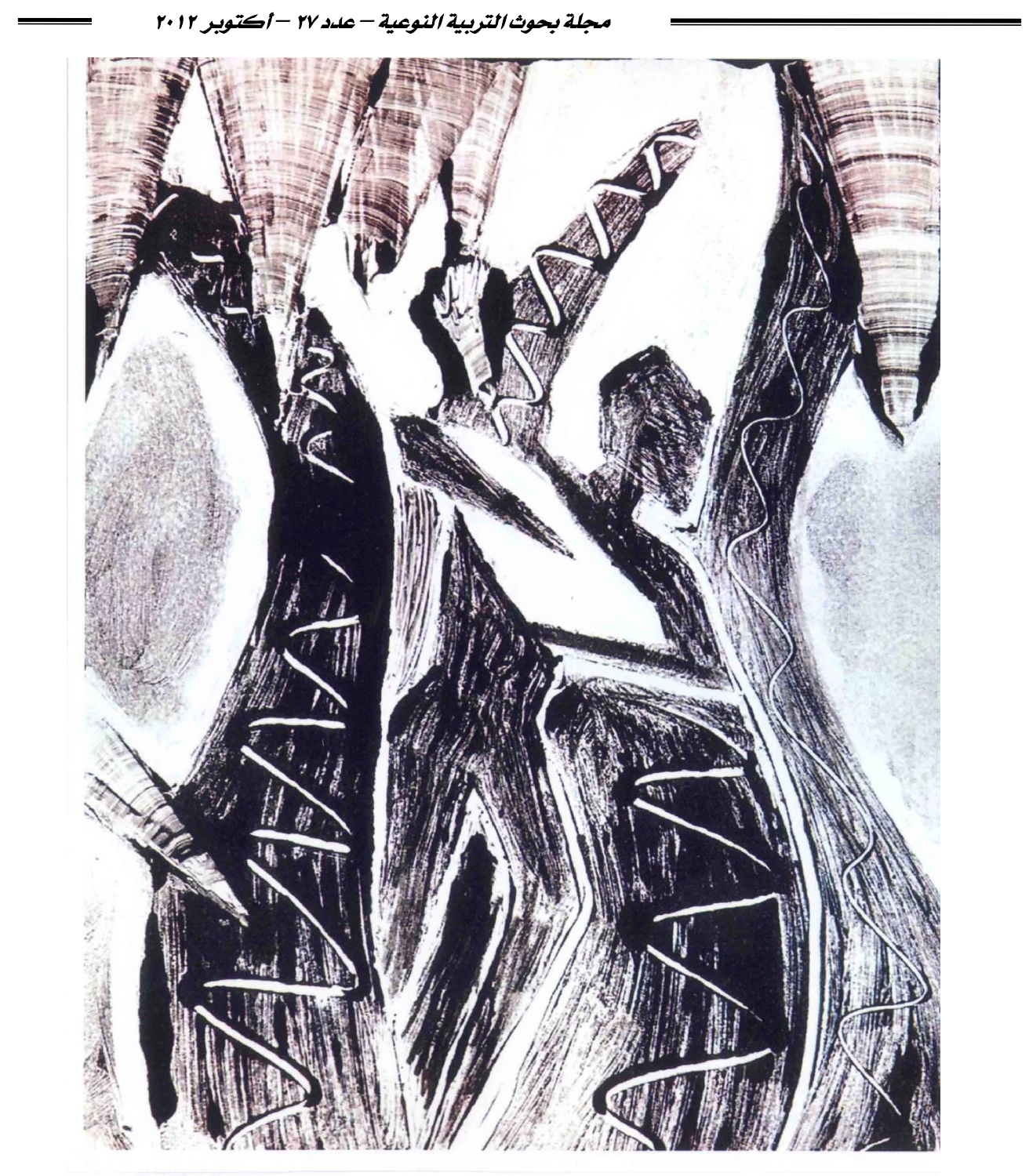

Work \# 1 
Work \# 2

Title: Refugee

Media: mono-print

Size: 8"x11"

Year: Fall, 2007

\begin{tabular}{|c|c|c|c|}
\hline $\begin{array}{c}\text { Groups } \\
\text { Categories }\end{array}$ & Color & Form & Interpretation \\
\hline $\begin{array}{l}\text { Emotional } \\
\text { disordered }\end{array}$ & $\begin{array}{l}\text { Gray- } \\
\text { black-dull color is } \\
\text { what these people } \\
\text { are wearing. }\end{array}$ & $\begin{array}{l}\text { Sheep } \\
\text { movement- group of } \\
\text { people moving more } \\
\text { towards center- other } \\
\text { left run away towards } \\
\text { center- get away- } \\
\text { muted shape- of caged } \\
\text { individual- } \\
\text { imprisoned- trapped- } \\
\text { egregious- } \\
\text { imprisonment- people } \\
\text { follow truce }\end{array}$ & 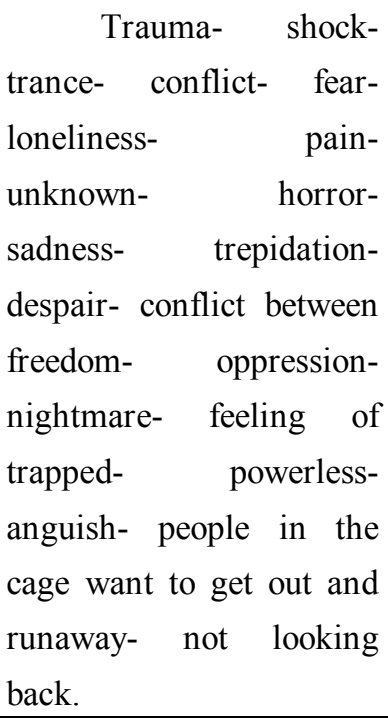 \\
\hline $\begin{array}{l}\text { First } \\
\text { Researcher } \\
\text { result }\end{array}$ & \multicolumn{3}{|c|}{$\begin{array}{l}\text { Aspect of a whole group has been perceived and distinguished. } \\
\text { Therefore, the color we perceive doesn't depends on size, surrounding, } \\
\text { and lighting but also on pigments, and on the characteristics of the } \\
\text { surface from which it is reflected (Clibborn, 1980, 21) The uses of the } \\
\text { colors on the groups against the background matched the law of closure } \\
\text { where familiar shapes are more readily seen as a complete because the } \\
\text { eye completed the line of these familiar shape and form and created a } \\
\text { whole. Sense of moving these figures towards prison had matched the law } \\
\text { of continuation where the eye followed the line and curve to adjoining } \\
\text { object. The law of proximity occurred because the groups are similar but } \\
\text { we don't know the number of these figure however, because of their } \\
\text { closeness to each other created a big group. }\end{array}$} \\
\hline
\end{tabular}




\begin{tabular}{|c|c|c|c|}
\hline $\begin{array}{l}\text { Normative } \\
\text { group }\end{array}$ & $\begin{array}{l}\text { collection of } \\
\text { pigments band- } \\
\text { red high light- } \\
\text { some green- dark } \\
\text { brown with red on } \\
\text { the back ground- } \\
\text { blend colors of } \\
\text { people clothes- } \\
\text { dessert color. }\end{array}$ & $\begin{array}{l}\text { group of people- } \\
\text { couple inside the } \\
\text { tent- two figures } \\
\text { in the middle } \\
\text { square- straight } \\
\text { line- big curvy } \\
\text { line- quick } \\
\text { strokes- figure } \\
\text { are in moving } \\
\text { motion. }\end{array}$ & 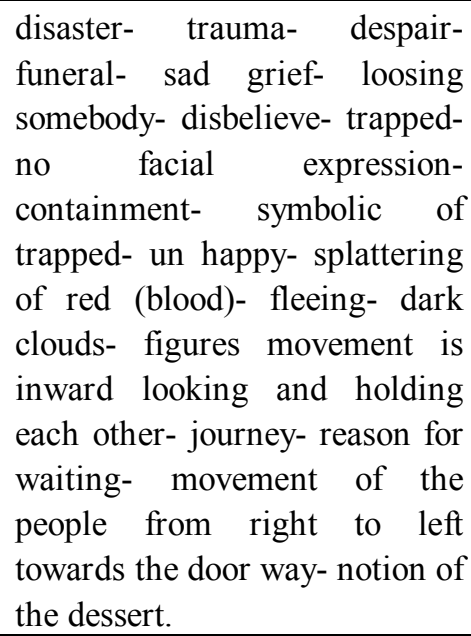 \\
\hline $\begin{array}{l}\text { First } \\
\text { Researcher } \\
\text { result }\end{array}$ & \multicolumn{3}{|c|}{$\begin{array}{l}\text { The law of closure had met the view of people walking with no facial } \\
\text { expression. The movement of the figures even they lack incomplete } \\
\text { details, had led the eye to see them as complete familiar form. The size } \\
\text { of these people and color had matched the law of similarity where the } \\
\text { eye sees similar shape, size, and color in a spatial location. The color of } \\
\text { grey, green olive, brown suggested the impression of sadness matter } \\
\text { which involve in our life like funeral, grief, trauma, unhappy...etc } \\
\text { because the color association are influenced from our specific cultures } \\
\text { (Zelanski \&Fisher,1998,31). The movement of the figures has met the } \\
\text { law of continuation where the eye follows the line till leads to a point. } \\
\text { This movement could apply in funeral or any sad event where people } \\
\text { walk after each other, holding hands, getting close to each other. }\end{array}$} \\
\hline
\end{tabular}




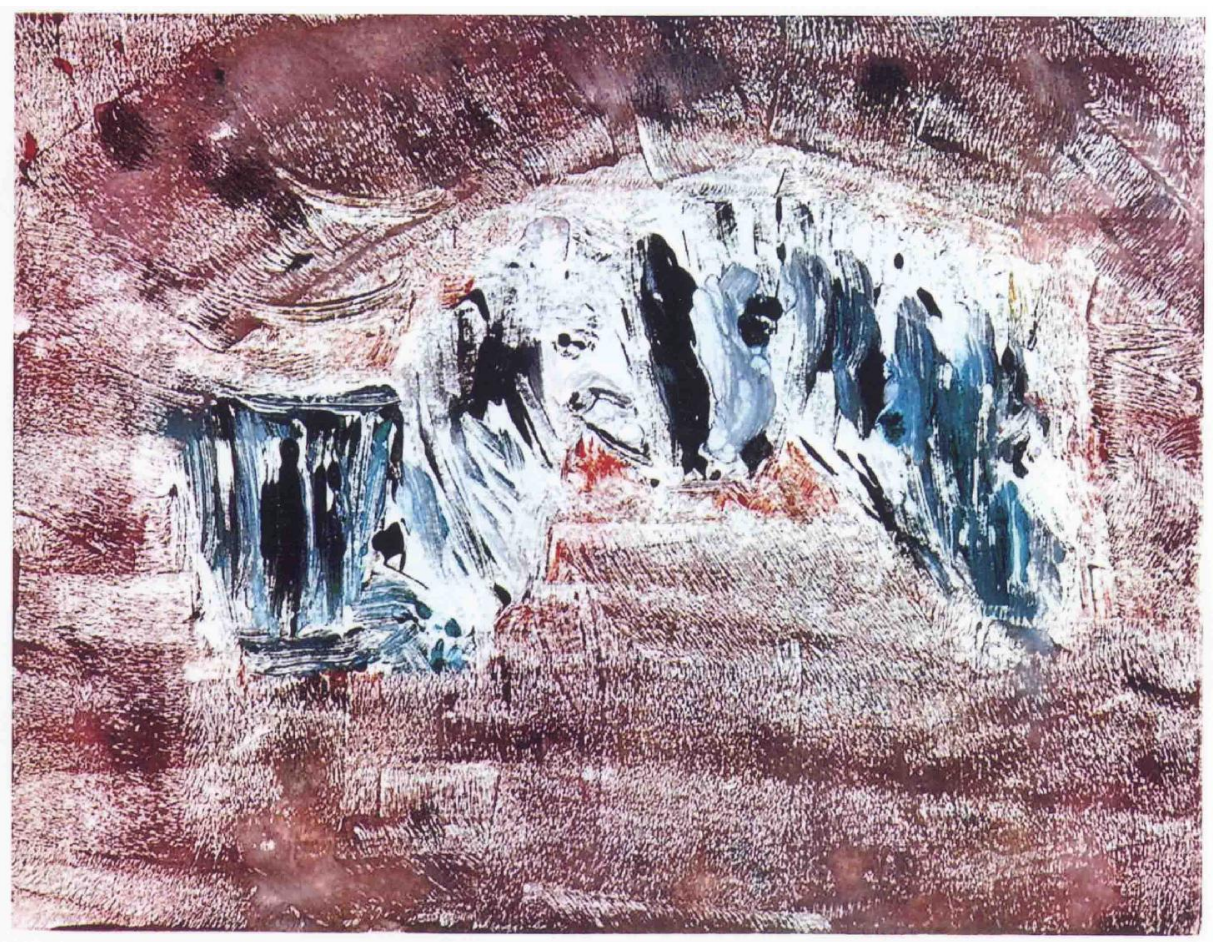

Work \# 2 
Work \# 3

Title: Liminal Dream Light

Media: mono-print

Size: 8"x11"

Year: Fall, 2007

\begin{tabular}{|c|c|c|c|}
\hline $\begin{array}{c}\text { Groups } \\
\text { ategories }\end{array}$ & Color & Form & Interpretation \\
\hline $\begin{array}{l}\text { Emotional } \\
\text { disordered }\end{array}$ & $\begin{array}{l}\text { Dark whole- } \\
\text { black center and } \\
\text { is central focus- } \\
\text { red reminds of } \\
\text { blood- blue } \\
\text { block- dark to } \\
\text { light. }\end{array}$ & $\begin{array}{l}\text { Door to un known- } \\
\text { focus looks like a } \\
\text { person perhaps hands- } \\
\text { space movement } \\
\text { towards light- up ward- } \\
\text { everything merged } \\
\text { together consciously } \\
\text { dark- down- stuck } \\
\text { between two dark light- } \\
\text { move towards vortex- } \\
\text { everything is guided } \\
\text { into it center- large } \\
\text { finger print- door to un } \\
\text { known. }\end{array}$ & 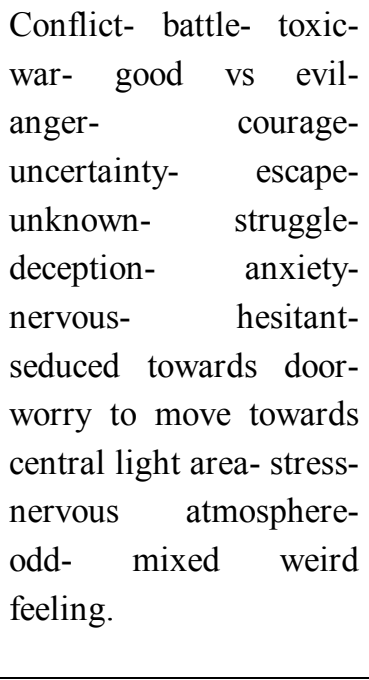 \\
\hline $\begin{array}{l}\text { First } \\
\text { Researcher } \\
\text { result }\end{array}$ & \multicolumn{3}{|c|}{$\begin{array}{l}\text { The block in the center which emphasized in black and blue and some } \\
\text { red had attracted the eye as a dark whole which match the first law of } \\
\text { equilibrium. The uses of black, blue, and red in the center had personal } \\
\text { effect on the group, however, they may be drawn toward color } \\
\text { representing qualities they lack, for balance (Zelanski \&Fisher, 1998, } \\
\text { 31). The size and location of the whole had made it more important for } \\
\text { the clients' to view it and symbolized as an eye. Disregard that there are } \\
\text { other parts in this image but the whole was more important than the } \\
\text { sum. Other separated elements on the right side of the image had given } \\
\text { the sense of movement; this movement had matched the law of closure } \\
\text { where the eye sees complete line rather than incomplete line. The form } \\
\text { of the whole was interpreted as a door to unknown. This view fall into } \\
\text { the law of similarity where the eye naturally grouped the form of the } \\
\text { color to see it as a shape. }\end{array}$} \\
\hline
\end{tabular}




\begin{tabular}{|c|c|c|c|}
\hline $\begin{array}{l}\text { Normative } \\
\text { group }\end{array}$ & $\begin{array}{l}\text { Blotches of red- } \\
\text { see blue then the } \\
\text { center color- } \\
\text { black center- } \\
\text { black on the } \\
\text { right side } \\
\text { occupied the } \\
\text { background vs } \\
\text { white on the left } \\
\text { side occupying } \\
\text { background. }\end{array}$ & $\begin{array}{l}\text { rectangular- shape in } \\
\text { the middle- texture in a } \\
\text { form of mesh in the } \\
\text { background- dots like } \\
\text { tree- clouds shaped } \\
\text { from blue\& red- center } \\
\text { shape forms like a } \\
\text { house - round shape } \\
\text { are more prominent- } \\
\text { oval shape. }\end{array}$ & $\begin{array}{l}\text { the division of the } \\
\text { background like interior } \\
\text { and exterior view- two } \\
\text { different places like } \\
\text { collage- slight } \\
\text { movement on the black } \\
\text { background- night life- } \\
\text { stop light- activity in the } \\
\text { city- shopping with the } \\
\text { family- stability- dark is } \\
\text { more safe than light } \\
\text { portion of the } \\
\text { background- rainy day- } \\
\text { walking pass by } \\
\text { buildings- children } \\
\text { drawing- reflection of } \\
\text { water- sky kindergarten } \\
\text { child world- kids drawn } \\
\text { on wet window- fun- } \\
\text { happy- nostalgic- } \\
\text { cleaning the house in the } \\
\text { center and trying to get } \\
\text { the black out. }\end{array}$ \\
\hline $\begin{array}{l}\text { First } \\
\text { Researcher } \\
\text { result }\end{array}$ & \multicolumn{3}{|c|}{$\begin{array}{l}\text { Black rectangular center was notified but also contrast the background } \\
\text { which divided the image into two parts and was notified as well. Red } \\
\text { blotches on the left side distracted the eye because color symbolism are } \\
\text { interpreted culturally different such as red is associated with vigorous } \\
\text { life in many cultures (Zelanski \& Fisher, 1998, 31). As a result, this } \\
\text { image had a balanced view towards the wholeness of viewing all } \\
\text { elements. This aspect matches Gestalt perception that the whole is more } \\
\text { important than the sum. Bright colors are connected with alert signal. } \\
\text { Blotches of color suggested water had run through the paint and } \\
\text { interpreted as an ordinary rainy day. The connection of color } \\
\text { symbolism related to the law of similarity where the eye similar shapes, } \\
\text { color to form familiar shape of present movement of people life. }\end{array}$} \\
\hline
\end{tabular}




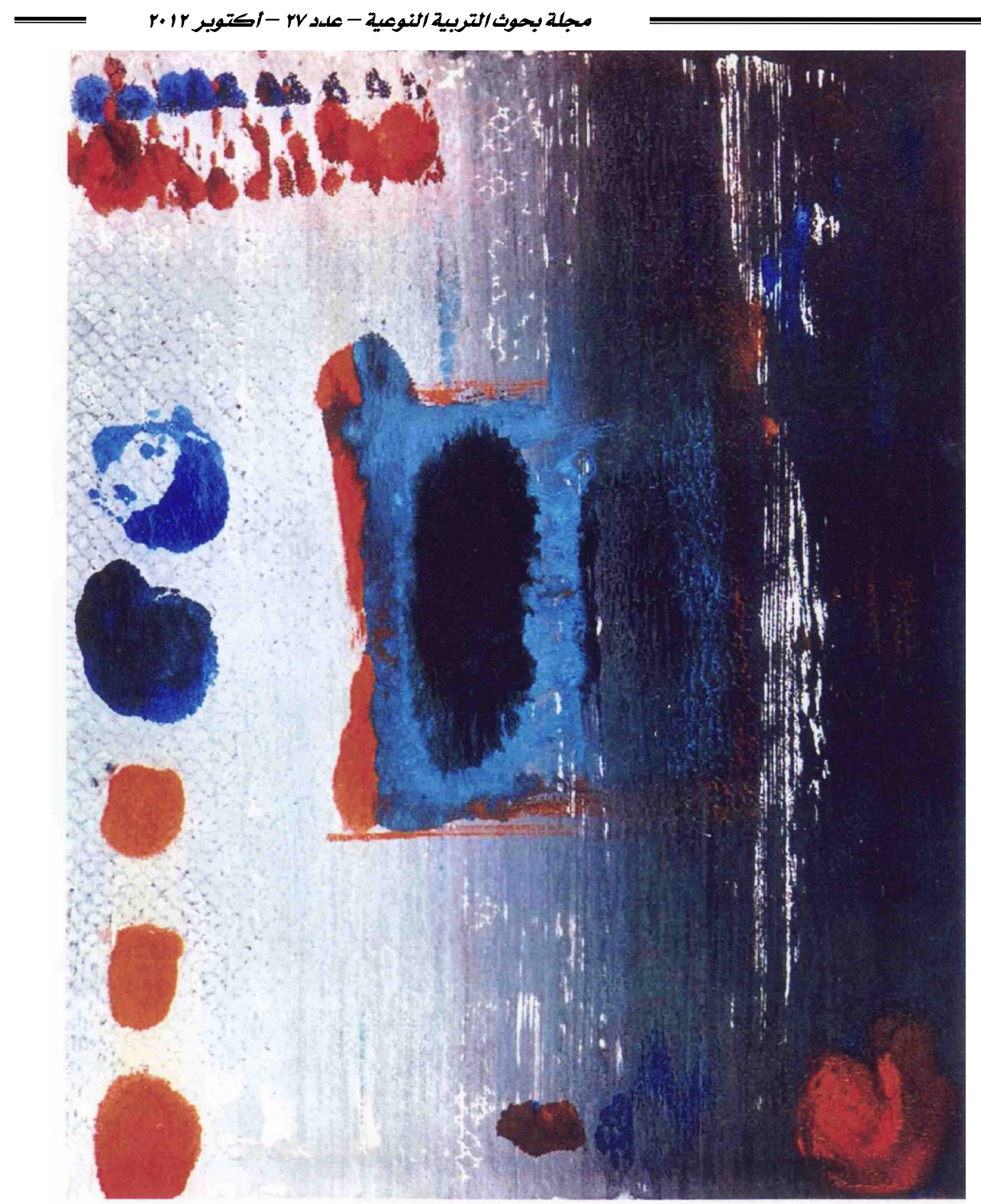

Work \# 3 
Work \# 4

Title: Untitled

Media: mono-print

Size: 8"x11"

Year: Fall, 2007

\begin{tabular}{|c|c|c|c|}
\hline $\begin{array}{l}\text { Groups } \\
\text { Categories }\end{array}$ & Color & Form & Interpretation \\
\hline $\begin{array}{l}\text { Emotional } \\
\text { disordered }\end{array}$ & $\begin{array}{l}\text { Pink long neck } \\
\text { flamingo- white lines- } \\
\text { yellow hole- different } \\
\text { shades of green. }\end{array}$ & $\begin{array}{l}\text { Form of birds- } \\
\text { positive image- } \\
\text { movement- } \\
\text { image flow } \\
\text { well- all pieces } \\
\text { go together. }\end{array}$ & $\begin{array}{l}\text { Happy- dreamlike- fantasy- } \\
\text { sporadic- disorganized } \\
\text { fragmental but positive- } \\
\text { ethereal- whimsical- linear- } \\
\text { yet chaotic- whimsical like a } \\
\text { dream- energy- up lifting- } \\
\text { positive- creating creativity- } \\
\text { continue to seek happiness- } \\
\text { inner child heal- darks spots- } \\
\text { feeling awkward- conflict- } \\
\text { being self vs feeling alone- } \\
\text { not accepted- trying to fit in- } \\
\text { break through the wall- non } \\
\text { threatening- no barriers. }\end{array}$ \\
\hline $\begin{array}{l}\text { First } \\
\text { Researcher } \\
\text { result }\end{array}$ & \multicolumn{3}{|c|}{$\begin{array}{l}\text { This is a relaxing image. Pink color and its form had symbolized a long } \\
\text { neck flamingo. Five responses of six had symbolized the form of pink as } \\
\text { flamingo which links that the aspect of image takes on culturally } \\
\text { accepted meaning that goes beyond its merely recognizable shapes } \\
\text { (Roukes, 1998, 105) The movement of the lines had given the shape of } \\
\text { different birds. The connection of these forms had given a significant to } \\
\text { an overall aspect of continuation. The movement of the lines falls in the } \\
\text { law of continuation where the eye follows the line and the curve of } \\
\text { connecting elements. The law of closure accrued when these elements } \\
\text { were connected and overlapped and the eye completed these lines of } \\
\text { curvy elements to form a shape of bird. All groups had noticed different } \\
\text { shades of green which occupied major background and highlighted the } \\
\text { aspect of calming and soothing. Green is consider relieves tension and } \\
\text { stabilizes emotion (Walker, 1991, 88). This emotion had translated in } \\
\text { interpreting the work as a positive and generated the feeling of happy. } \\
\text { The shades of green had a sense of continuation for the viewers, because } \\
\text { the background is consider the environment for the elements where the } \\
\text { eye follow smoothly forms of color to join them together. This view falls } \\
\text { in the law of continuation. This work contains Arabic calligraphy and the } \\
\text { script was connected letters, this connection gave the form of birds where } \\
\text { the light pink color vs green in the background the form of bird in the } \\
\text { green. }\end{array}$} \\
\hline
\end{tabular}




\begin{tabular}{|c|c|c|c|}
\hline group & $\begin{array}{l}\text { Pink- green\& blue } \\
\text { shades in the } \\
\text { background- yellow \& } \\
\text { white interwoven with } \\
\text { calligraphy- rich } \\
\text { colors- earth tones. }\end{array}$ & $\begin{array}{l}\text { Script- } \\
\text { calligraphy- } \\
\text { flamingo- tree } \\
\text { trunk- moon- } \\
\text { wavy lines of } \\
\text { the } \\
\text { calligraphy- } \\
\text { rocks- circles } \\
\text { shaped of } \\
\text { colors on the } \\
\text { background- } \\
\text { candy can- } \\
\text { squiggly } \\
\text { shapes. }\end{array}$ & $\begin{array}{l}\text { weaving carpet- set of } \\
\text { movement letters embedded } \\
\text { with background- business } \\
\text { of elements in nature- } \\
\text { energize- flow background } \\
\text { movement- dawn time- } \\
\text { evocative- awake- alert- } \\
\text { excitement alert- attention- } \\
\text { listen- richness of color has } \\
\text { deep meaning- script against } \\
\text { lush forest- relaxing- blue in } \\
\text { the background forms like } \\
\text { branches- positive- soft- } \\
\text { feminine- } \\
\text { soothing- camping- } \\
\text { reminiscence- memories } \\
\text { through wood- flowers- } \\
\text { plants- being in the park- } \\
\text { movements everywhere- all } \\
\text { direction- anticipating. }\end{array}$ \\
\hline $\begin{array}{l}\text { First } \\
\text { Researcher } \\
\text { response }\end{array}$ & \multicolumn{3}{|c|}{$\begin{array}{l}\text { The movement of pink script highlighted the whole image in different } \\
\text { direction which led the eye to continue following the ends of this script } \\
\text { which as a result felled in the law of continuation where the eye follow } \\
\text { the connecting elements. The entire group had recognized the script but } \\
\text { didn't know the meaning because it was in different language. However, } \\
\text { the script had form, objectives definition, and significance against green } \\
\text { background. The shade of the pink color had spot out these elements } \\
\text { against different shades of green and blue in the background which gave } \\
\text { the sense of bird in the jungle. This notion matched the law of closure } \\
\text { where the shapes are seen as complete and form a familiar shape. The } \\
\text { form of green color in the background had given the sense of forest even } \\
\text { though, there is no real form of trees or plants, and however the blend of } \\
\text { these shades had created the form of leaves and branches. Five responses } \\
\text { of six had connected the meaning of these forms versus background } \\
\text { because a created form can be based on reality, recognizable or abstract- } \\
\text { unrecognizable. This blend matches the law of similarity where we see } \\
\text { similar shape, size, and color on familiar environment. Symbolism of } \\
\text { green generates relaxing and soothing, however, crowded forms in the } \\
\text { background generates alert of attention while walking inside the forest. }\end{array}$} \\
\hline
\end{tabular}




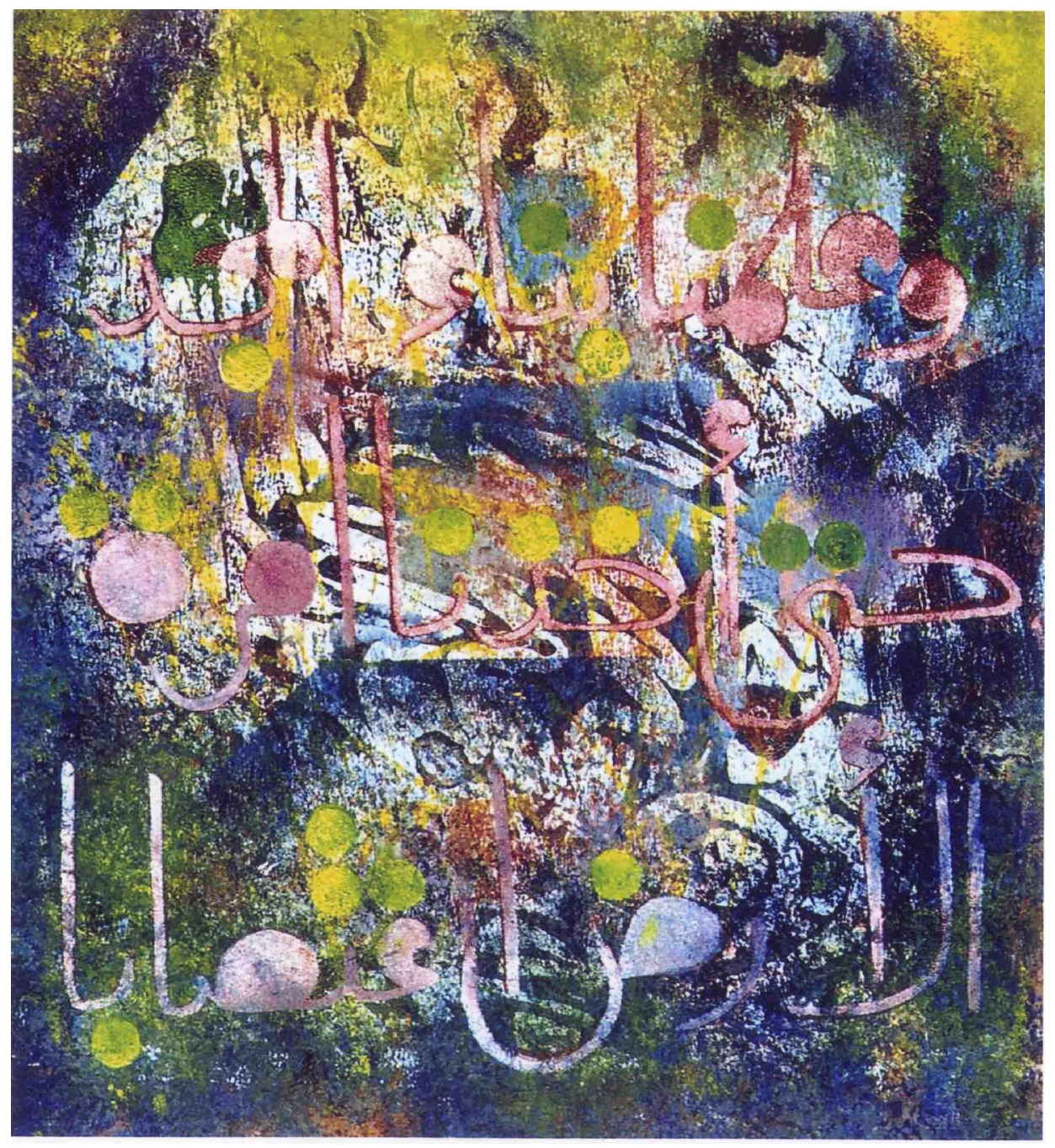

Work \# 4 
Work \# 5

Title: Modernity

Media: Mono print

Size: 8"x11"

Year: Fall, 2007

\begin{tabular}{|c|c|c|c|}
\hline $\begin{array}{l}\text { Groups } \\
\text { Categories }\end{array}$ & Color & Form & Interpretation \\
\hline $\begin{array}{l}\text { Emotional } \\
\text { disordered }\end{array}$ & $\begin{array}{lr}\text { White } & \text { line- } \\
\text { yellow } & \text { pole- } \\
\text { people } & \text { in } \\
\text { different } & \\
\text { colors- } & \text { blue } \\
\text { wall. } & \end{array}$ & $\begin{array}{l}\text { Person cut out- } \\
\text { Forms of people- } \\
\text { berried person- } \\
\text { yellow wall } \\
\text { obstructs pole- } \\
\text { barrier between the } \\
\text { pieces- important } \\
\text { between the whole } \\
\text { and the pieces- } \\
\text { pieces together but } \\
\text { not self. }\end{array}$ & $\begin{array}{l}\text { Neutral emotion- moderate- } \\
\text { more modernism- no real } \\
\text { movement- some white sterile- } \\
\text { happy but not blissful- focus } \\
\text { missing- feeling blocked- unable } \\
\text { to cross over- make a stereo } \\
\text { typical identification- wall like a } \\
\text { mountain- one can move it- wall } \\
\text { keeps from break in through- } \\
\text { want to tear down barrier- other } \\
\text { non- encouraging- battle- } \\
\text { struggle- conflict- power vs } \\
\text { force- power struggle- stand still- } \\
\text { all pushing towards a wall- } \\
\text { separateness. }\end{array}$ \\
\hline $\begin{array}{l}\text { First } \\
\text { Researcher } \\
\text { result }\end{array}$ & \multicolumn{3}{|c|}{$\begin{array}{l}\text { This is an abstract image where yellow pole is displayed on blue } \\
\text { background interlaced with some other colors that had been interpreted as } \\
\text { a human figure. All groups had viewed the yellow pole as a whole and } \\
\text { then recognized the blue. Yellow color usually generates energy for the } \\
\text { muscles, where blue is consider balancing color and reduces nervous } \\
\text { excitements. So, function of yellow color has more effect on organism } \\
\text { and person than blue. The sum of the parts which emphasized people in } \\
\text { different color had fallen in the law of proximity where the eye groups } \\
\text { similar elements together or nearness. The connection of the figures } \\
\text { together had generated feeling of conflict. Five responses of six } \\
\text { mentioned the blue texturized background as a wall that conveys meaning } \\
\text { of struggle, power, and conflict. The size of the background as formed } \\
\text { with color blue had given the impression of no movement that can } \\
\text { generate moderate feeling but cannot be changed. This interpretation falls } \\
\text { in the law of similarity where the eye could see thing similar to reality and } \\
\text { name it because of its size. The uses of these colors had generated neutral } \\
\text { and moderate emotion. }\end{array}$} \\
\hline
\end{tabular}




\begin{tabular}{|c|c|c|c|}
\hline oup & $\begin{array}{l}\text { yellow cylinder } \\
\text { cause } \\
\text { distraction- } \\
\text { three dots of } \\
\text { color- blue in } \\
\text { the background } \\
\text { like cold } \\
\text { landscape. }\end{array}$ & $\begin{array}{l}\text { tree- organic } \\
\text { circles- head\& tail- } \\
\text { organic circles on } \\
\text { the tree- textures of } \\
\text { jungle in the } \\
\text { background in } \\
\text { blue. }\end{array}$ & $\begin{array}{l}\text { wild forest- documentary in } \\
\text { Amazon forest- tribal- primitive } \\
\text { life where people sign on trees- } \\
\text { alert looking for danger- } \\
\text { wariness of fear- gravity falls in } \\
\text { the element- panic from blue } \\
\text { movement in the background- } \\
\text { dangerous environment- } \\
\text { confusions- things rolling down } \\
\text { the hill and hit a brick wall- busy } \\
\text { street- traffic light- people } \\
\text { crossing the street- a lit of } \\
\text { building- community- daily } \\
\text { running- safe routine- no risk. }\end{array}$ \\
\hline $\begin{array}{l}\text { st } \\
\text { searcher } \\
\text { ult }\end{array}$ & \multicolumn{3}{|c|}{$\begin{array}{l}\text { Interpretations fell into two parts: } \\
\text { Yellow cylinder viewed as a tree trunk on a cold landscape with the } \\
\text { emphasis of colored dots on the tree and colored organic elements on the } \\
\text { right side of the image. This is the symbol of elements that convey } \\
\text { meanings in mind, where yellow has energy effect on person. } \\
\text { Four responses of six had mentioned rush hour of a busy street where } \\
\text { there is a traffic light and people crossing the street passing by a lot of } \\
\text { buildings, and viewed as a daily running life in such community. These } \\
\text { interpretation felled in the perception of the whole, where the whole is } \\
\text { more important than the sum of the parts. Moreover, the law of closure } \\
\text { fits in the description where the eye completes the line and curve to form } \\
\text { familiar shapes. Four responses of six interpret the routine of daily life } \\
\text { which emphasized by the path of color which generates safe feeling. Five } \\
\text { responses of six interpret the image as forest life that sometimes involves } \\
\text { primitive life which could generates alert of dangerous. }\end{array}$} \\
\hline
\end{tabular}




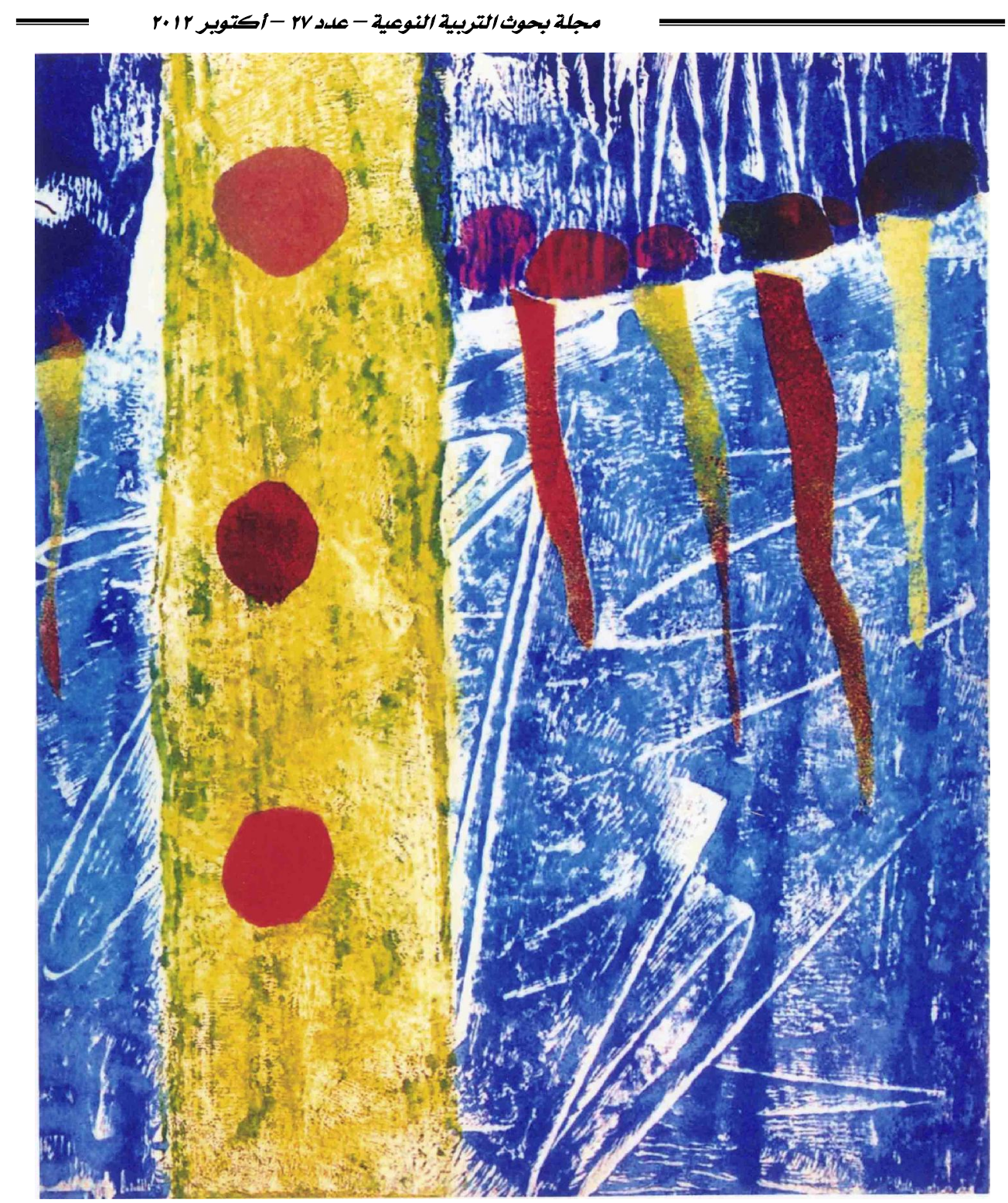

Work \# 5 
Work\# 6

Title: Mystical confusion

Media: mono print

Size: 8"x11"

Year: Fall, 2007

\begin{tabular}{|c|c|c|c|}
\hline $\begin{array}{l}\text { Groups } \\
\text { Categories }\end{array}$ & Color & Form & Interpretation \\
\hline $\begin{array}{l}\text { Emotional } \\
\text { disordered }\end{array}$ & $\begin{array}{l}\text { Eye in the } \\
\text { middle } \\
\text { against light } \\
\text { background- } \\
\text { blood next to } \\
\text { thorn- blue } \\
\text { waves- colors } \\
\text { in the } \\
\text { background } \\
\text { like a wall- } \\
\text { darker earthy } \\
\text { color at the } \\
\text { bottom. }\end{array}$ & $\begin{array}{l}\text { Walls across } \\
\text { the back- form } \\
\text { of waves- } \\
\text { smooth lines- } \\
\text { tranquil- } \\
\text { soothing- eye } \\
\text { is the main } \\
\text { focus piercing } \\
\text { thorns on the } \\
\text { left- see a } \\
\text { person. }\end{array}$ & $\begin{array}{l}\text { Eye sadness and cry- tearing in pain- } \\
\text { there is a momentum watchful- feeling } \\
\text { trapped- powerless- dominating } \\
\text { control- adjacent to the twigs- see } \\
\text { other plight- relaxing feel- curiosity- } \\
\text { concern- questioning- looking deep } \\
\text { within and yet outward glare- } \\
\text { insecurity (fear conflict)- things going } \\
\text { on with others only a passive } \\
\text { participant can only watch- feeling as } \\
\text { if can only watch the movement of the } \\
\text { life- need to open wider- somewhat } \\
\text { middle seem safe haven. }\end{array}$ \\
\hline $\begin{array}{l}\text { First } \\
\text { Researcher } \\
\text { result }\end{array}$ & \multicolumn{3}{|c|}{$\begin{array}{l}\text { The entire group had common answer that the eye in the middle is located } \\
\text { against the background. This kind of eye provoked too many questions } \\
\text { regarding the direction, meaning, and what it conveys. The eye as a form } \\
\text { in our visual experience could influence our perception in looking at it } \\
\text { and its relation with background (wong, 1993, 138). All groups had } \\
\text { viewed the eye as a whole and then tried to locate its status in the image. } \\
\text { The eye is located in the middle between the sky and the bottom is } \\
\text { formed with color blue or waves where the bottom represented with } \\
\text { earthy color to symbolize ground. Four responses of six interpret the } \\
\text { status of the eye and question it's watching, but not controlling. The color } \\
\text { of the top and bottom had fulfilled the law of similarity where the eye } \\
\text { sees things similar in nature. Blue represented for sky, earthy color for the } \\
\text { ground and then tried to explain the status between these two elements. } \\
\text { Moreover, three responses of six interpret the shape of the eye is not } \\
\text { aggressive but rather has relaxed feeling, trapped, and pain. All groups } \\
\text { interpret earthy colors that generate feeling of autumn with heavy darker } \\
\text { color. Everything in nature turns to dry and fall gradually, but in a smooth } \\
\text { way that everybody watches this concept of changing in a wider range. } \\
\text { Five responses of six interpret the gradation of color from top to bottom } \\
\text { which emphasized different seasons and different way. These ways } \\
\text { generates insecurity (fear) or security (safe). This gradation falls in the } \\
\text { law of continuation where the eye follows the blue sky then the eye with } \\
\text { the background moves down to the earth. }\end{array}$} \\
\hline
\end{tabular}




\begin{tabular}{|c|c|c|c|}
\hline $\begin{array}{l}\text { Normative } \\
\text { group }\end{array}$ & $\begin{array}{l}\text { dark color of } \\
\text { shallow eye } \\
\text { against white } \\
\text { background- } \\
\text { top blue- } \\
\text { white } \\
\text { middle- } \\
\text { earthy color } \\
\text { at bottom. }\end{array}$ & $\begin{array}{l}\text { eye in the } \\
\text { middle- } \\
\text { fracture lines- } \\
\text { wheal- grass- } \\
\text { fish- oval- } \\
\text { rectangular- } \\
\text { shape of sky } \\
\text { on the top- } \\
\text { ocean } \\
\text { creatures. }\end{array}$ & $\begin{array}{l}\text { Fishy eye- control moving- ocean- } \\
\text { clouds- depressing- horrified eye- } \\
\text { recent events: murder on the news- } \\
\text { question- desolate- feared- confusion- } \\
\text { wheal looking for food- top part of } \\
\text { blue represent danger where wheal } \\
\text { movement are presented- fear of } \\
\text { sharks- coral reef- sharks circling\& } \\
\text { waving- life in water- the image has } \\
\text { three planes: bottom more stable, } \\
\text { middle has more movement, top } \\
\text { movement is calm, top and bottom } \\
\text { squeezing over middle which trapped } \\
\text { middle section- terrene environment- } \\
\text { war- very sad-aggression- threatening- } \\
\text { inner thinking memory- clarify } \\
\text { internal. }\end{array}$ \\
\hline $\begin{array}{l}\text { First } \\
\text { Researcher } \\
\text { result }\end{array}$ & \multicolumn{3}{|c|}{$\begin{array}{l}\text { The entire group interprets the eye or the form of fish in the middle and } \\
\text { its connection and location with the surroundings as a whole which } \\
\text { matched the law of proximity. The law of proximity states that the line or } \\
\text { edges makes it easier for the eye to group the main element and } \\
\text { surrounding as one composition. The entire group interprets the image } \\
\text { into three parts and divides it into three familiar color groups which } \\
\text { helped the interpreter to identify the reality of this image. This } \\
\text { identification matched the law of similarity where the eye sees similar } \\
\text { shape, color, and size in spatial location. Five responses of six interpret } \\
\text { the image as life in water which usually suggests fear, danger, } \\
\text { trapped...etc. This formation matched the law of closure where the eye } \\
\text { completes the lines to form familiar shape. Three responses of six } \\
\text { interpret movement which occurred from top and middle part which } \\
\text { allowed the eye to continue search for the rest of the image. Continuation } \\
\text { occurred then the eye followed the line movement of an adjoining object. }\end{array}$} \\
\hline
\end{tabular}




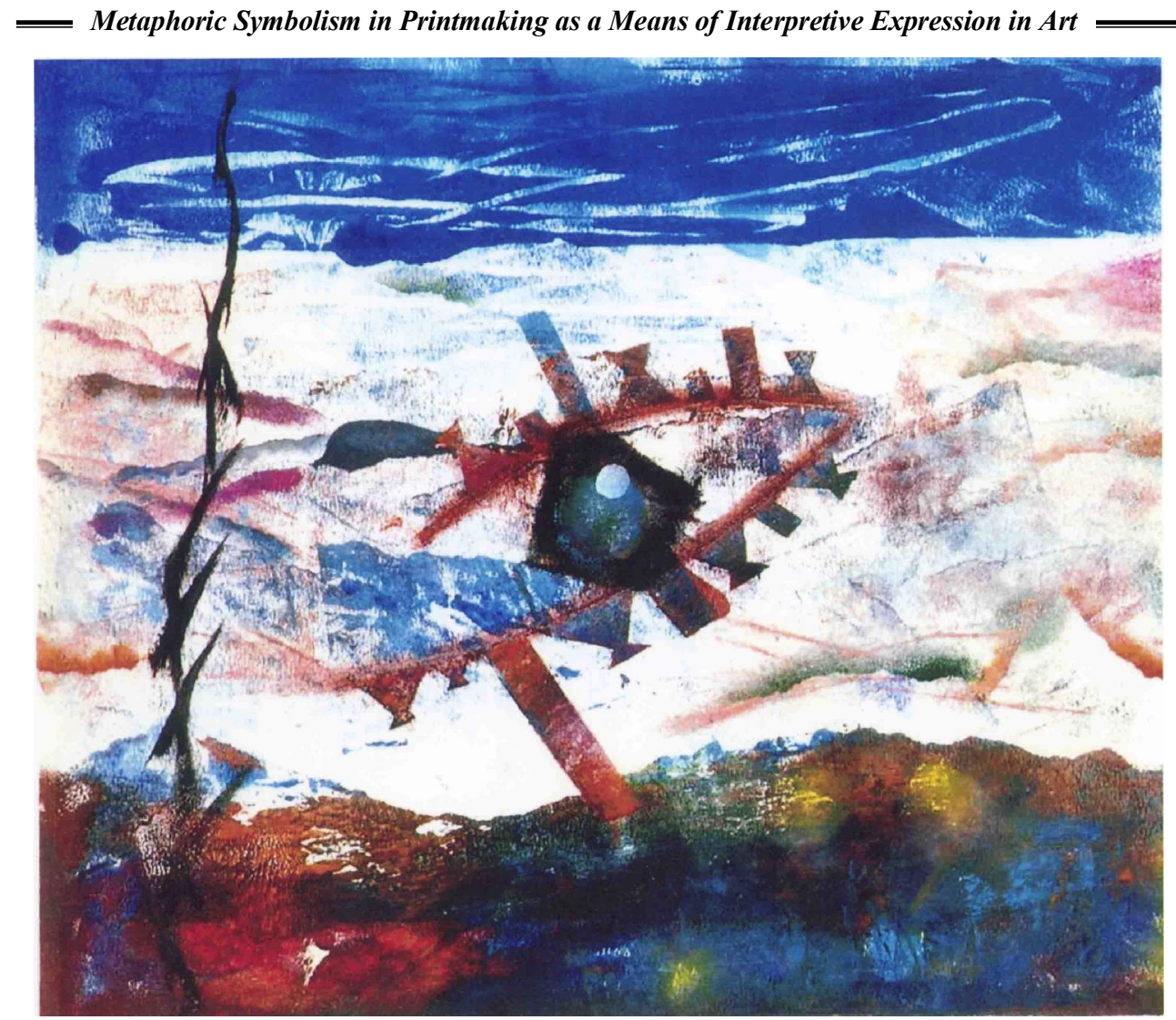

Work \# 6 
Work \# 7

Title: Miss understood

Media: mono print

Size: 8"x11"

Year: Fall, 2007

\begin{tabular}{|c|c|c|c|}
\hline $\begin{array}{l}\text { Groups } \\
\text { Categories }\end{array}$ & Color & Form & Interpretation \\
\hline $\begin{array}{l}\text { Emotional } \\
\text { disordered }\end{array}$ & $\begin{array}{l}\text { Brown yarn } \\
\text { and } \\
\text { ribbons- } \\
\text { string- red } \\
\text { torn } \\
\text { triangle- } \\
\text { blood- blue } \\
\text { triangle on } \\
\text { the left- } \\
\text { writing. }\end{array}$ & $\begin{array}{l}\text { The form of yarn and ribbons } \\
\text { and string caught the eye then } \\
\text { form of writing- writing sums } \\
\text { up the image- scribble and } \\
\text { writing are the most } \\
\text { important in the image- if we } \\
\text { follow these elements one } \\
\text { thing leads to another- } \\
\text { movement with lines "Thank } \\
\text { you please do not help me } \\
\text { thank you". Finger print- the } \\
\text { forms falling apart- get point } \\
\text { into the foreground- all } \\
\text { moves towards one- } \\
\text { exclamation mark- } \\
\text { everything inter connected. }\end{array}$ & $\begin{array}{l}\text { Confusion- yet connection- angry- } \\
\text { questionable thought about it- } \\
\text { assertive need to be heard- } \\
\text { hesitant- independent yet feeling } \\
\text { somewhat miss understood- need } \\
\text { to stand out- chaotic yet control- } \\
\text { conflict push/ pull need to be } \\
\text { heard- attempting to put } \\
\text { everything together- trying to sort } \\
\text { everything out- bond together } \\
\text { again- processing- what is life to } \\
\text { live as or to question the status of } \\
\text { frustration- independent- fear- } \\
\text { resist- passive behavior- goals } \\
\text { optimistic- wanting to do } \\
\text { something significant- tension- } \\
\text { boxed in- yet attempting to cry } \\
\text { out. }\end{array}$ \\
\hline $\begin{array}{c}\text { First } \\
\text { Researcher } \\
\text { result }\end{array}$ & \multicolumn{3}{|c|}{$\begin{array}{l}\text { The entire group noticed the movement of the yarn or ribbons and attracted the } \\
\text { eyes from the first look at the image trying to follow their directions and how } \\
\text { they connect the pieces together to emphasize an idea out of this composition. } \\
\text { If the eye follows the direction of these organic lines (yarn \& ribbons), it will } \\
\text { leads to the bottom where is writing had been displayed in dark green. The law } \\
\text { of continuation falls in where the eye followed these organic elements in a } \\
\text { smooth way till the bottom where it leads to another form of writing. All the } \\
\text { group interprets the sum of the parts which symbolized in torn triangle red } \\
\text { color as blood, because red color had rays produce heat vitalize and energize } \\
\text { the liver which effect the person. Blue negative triangle symbolizes the } \\
\text { question of frustration. Although the blue color is balancing and relaxing but } \\
\text { the size and the form where it applied had raised a question. This status } \\
\text { emphasized law of similarity where the eye can see things similar to their } \\
\text { spatial location. Despite the connection of the composition elements, four }\end{array}$} \\
\hline
\end{tabular}




\begin{tabular}{|c|c|c|c|}
\hline & \multicolumn{3}{|c|}{$\begin{array}{l}\text { responses of six interpret the bright colors and disconnected the organic } \\
\text { elements to give attention towards the writing. Confusion appeared in the } \\
\text { process questioning attention to that person. Five responses of six interpret the } \\
\text { meanings of the words convey independency but on the other hand provokes } \\
\text { angry towards the need of replying. The location of these writing at the bottom } \\
\text { of the image had connected the law of proximity where the closer elements } \\
\text { are, the more likely we will see them as a group. Contrast colored displayed to } \\
\text { emphasize the anger yet there is a resisting view displayed in the organic } \\
\text { elements that connected the whole image. }\end{array}$} \\
\hline & \begin{tabular}{|l|} 
brown and \\
green string- \\
red drops- \\
blue \\
exclamation- \\
triangle- \\
words in \\
green
\end{tabular} & $\begin{array}{l}\text { triangle- } \\
\text { moving } \\
\text { thread- } \\
\text { exclamation- } \\
\text { words- swirl v } \\
\text { shapes- } \\
\text { fractures } \\
\text { destroyed } \\
\text { pieces from } \\
\text { whole- } \\
\text { geometric } \\
\text { shapes. }\end{array}$ & $\begin{array}{l}\text { string movement hold the pieces- cracked piece, } \\
\text { then letters- red on the right side is very strong } \\
\text { against background- attempt- broken heart- } \\
\text { blood- other part is setting of person- extreme- } \\
\text { cry for help that's why implementing letter- } \\
\text { people when they cannot do well on the image, } \\
\text { they go for writing to express more- shattered- } \\
\text { entangled- confused- distress- hopeless- fear- } \\
\text { unknown- multifaceted- multi sensory- } \\
\text { psychotic breakdown- emotional confused- } \\
\text { varied emotions- rearranging self- injustice- } \\
\text { anger- whimsical- view from NYC central park- } \\
\text { kite flying away- blue exclamation signifies } \\
\text { light from NY tower. }\end{array}$ \\
\hline & \multicolumn{3}{|c|}{$\begin{array}{l}\text { The entire group interprets organic elements (string) moving randomly around } \\
\text { other elements and heading towards the bottom of the image. Red triangle was } \\
\text { signified because of its location, size, and color against white background } \\
\text { suggest for all interpreter the idea of broken heart. This understanding } \\
\text { matched the law of similarity where we naturally group elements by similar } \\
\text { appearance or representation of the elements to high light the theme in shape, } \\
\text { size, and color. The law of continuation occurred when the entire group } \\
\text { followed the string movement that holds all elements and went down to the } \\
\text { bottom questioning variety of emotions that happening in this image. } \\
\text { Although, red symbolized heat, blue is relaxing, earth color is moderate; five } \\
\text { responses generated feeling of anger and confusion. Red, blue, earthy color } \\
\text { had been used in dark green and brown had symbolized for the interpreter } \\
\text { emotional confusion and trying to figure out why is the broken script, what's } \\
\text { the reason for disconnecting, and what's the reason of this shattered. }\end{array}$} \\
\hline
\end{tabular}




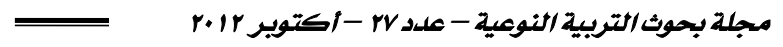

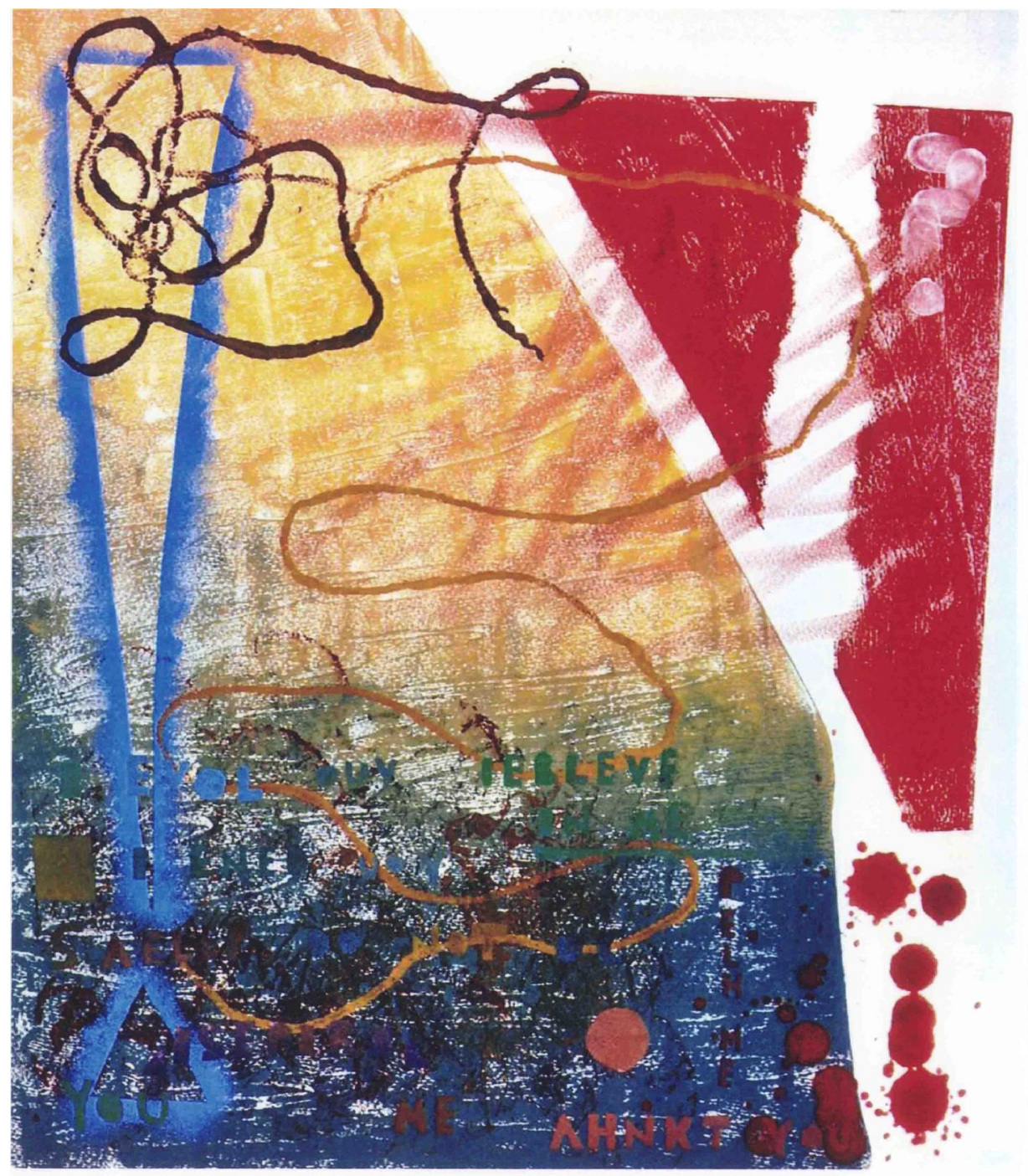

Work \# 7 


\section{Conclusion}

Normative individuals tended to be limited by their cultural perspective, while individuals with emotional disordered are clearly not bound by cultural limitations. Realities are not filtered by the immediate environment. Emotional disorder individual ability had been noticed to see the parts more clearly than just focus on the whole. Perhaps there is due to their individual splinting or fragmentation, or they are not as bound by five senses and see the images in a more symbolic and metaphoric manner as opposed to a literal interpretation by the normative group.

Intentionality, perhaps wanting to see more than just the whole and looking beyond the concrete reality to find the inner message, the print evokes, just like reflects their viewing as looking to find the inner meaning in their own existence. Breaking free of cultural norms and finding meaning in abstract forms, shapes, colors, and design. A more visceral and acute response, not necessarily a primitive one, but not literal either, perhaps a more expansive adventurous approaches to seeing images.

The image allows each person to perceive what it needs to understand in order to heal. It creeks a living picture show, the situations that are necessary to bring into wholeness the aspects of each individual to heal. The image is a learning vehicle, the image exquisite intimate to the needs of each individual. Always each situation serves each person involved. The image for each individual is cracked by their intentions. The image is malleable. This does not mean that what is created jointly within the image does not have an independence of the individual that participated in its interpretation. It means that there is no perception that cannot be changed or replaced with another.

The Gestalt allows the individual to detach him/her from the image and therefore to see it from knowledgeable perspectives and see it in action. It brings about the power of awareness and knowledge which can be identified in these interpretations. It's shaped by the configuration of each personality, the unconscious intentions. The intentions shape the personalities, illusion its reality within, until they are replaced by other intentions, unconscious or conscious. 
Each image, draws to itself personalities with consciousness of like frequency or like weakness, the law of attraction. The law of attraction creates the cocoon, so to speak of like energy around each image. The human emotional system can be broken down into roughly two elements: fear and love. For those with dysfunctional, filtering, fear was with emotional dysfunctionalism, though not bound by cultural filtering. The Gestalt, inverted, they were more bound in fear and found a symbol of fear in most of the images, while the normative though were culturally affected. They tended to stay within the literal and not to go beyond. It appeared they were not emotionally connection to the images as were the emotionally disordered group. The images had a more personal and impact meaning for that group while for normative group have a more detached and knowledge based interpretation.

\section{Questionnaire}

1. What caught your eye when looking at the art work?

2. What ideas and emotions does this work of art convey?

3. Describe what you see in this art work?

4. Describe the line \& shapes that you see in this art work? What shapes do you see most of? And what feelings if any do those shapes generate in you?

5. Which is the most important shape or object and why?

6. Do any of these pictures remind you of your own life story? Or of another story you know?

7. Imagine yourself in this image: what are you doing? How are you feeling or what is going on in this picture?

8. What emotion does this work of art express to you?

9. Do you see movement in this work of art? Where does it take you safe or feared place? How do the shadows, lines, and shapes make it seem that way?

10. How does the title of this work affect your understanding or appreciation of it? If you could give it a new title, what would be and why? 


\section{References}

1. Arnheim, Rudolf (1969). Visual Thinking. London, University of California Press. Ltd.

2. Avnston, Amy (2003). Graphic Design Basic. California, Wadsworth and Thomson Learning. Inc.

3. Clibborn, Edward (1980) Baroni, Daniel. Graphics. London, Thames and Hudson Ltd.

4. Dorset \& Baber (1990). Webster's new Universal Unbridged Dictionary. U.S.A, Simon \& Schuster, a Division of Gulf \& western corporation.

5. Jackson, Lan (2008). Gestalt: Alearning Theory of Graphic Design Education. Blackwell publishing Ltd. Volume 27, Number 1.

6. Roukes, Nicholas (1988). Design Synectics. Massachusetts, Davis Publication.

7. Malchiodi, Cathy (2007). The Art Therapy Sourcebook. New York, McgrawHill Publisher.

8. Saff, Donald, Sacilotto, Deli (1980). Printmaking: History and Process. New York, Holt, Rinehart and Winston Publisher.

9. Walker, Morton (1991). The power of color. U.S.A., Mcgraw-Hill Publisher Inc.

10. White, Lucy (2002). Printmaking as Therapy. London, Jessica kingsely Publisher Ltd.

11. Wong, Wucius (1993). Principles of Form and Design. Canada, John Wiley \& sons, Inc.

12. Zelanski, Paul \& Fisher, Mary (1989). Colour: For designer and Artists. London, The Herbert Press Ltd.

13. (1994) DSM. (Diagnostic Criteria). 


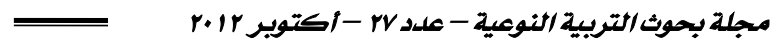

\section{المعاني الجازية للرهمز في الطباعة كوسيلة لبزجمة التعابير في الفن}

\section{لدى الأفراد الطبيعيين وذوي الاضطرابات العاطفية.}

$$
\text { الملـخص العـربى }
$$

تمثل الطباعة واجهة مميزة للمعالج النفسي، فيتيح مفهوم التعـدد الطبـاعي عمليـة تفاعل

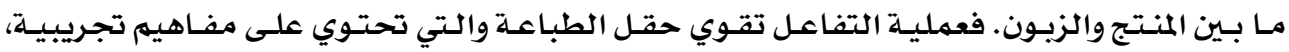

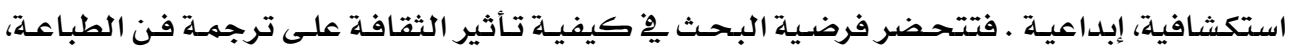

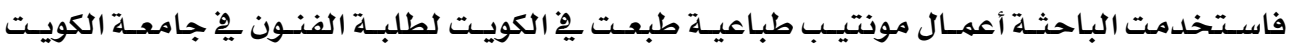
لاختبار نظرية بأن الفن أصبح شكل عالمي من أثكال الإبداع والذي يعزز الجميع بالنظر إليه وترجمته بطرق فردية مختلفة. ولاكتشاف تأثير الثقافات على ترجمة الفن الطبـاعي قسمت الباحثة العينـات إلى مجموعتين من المواطنين الأمريكيين: 1- مجموعة الأفراد الطبيعيين.

ץ- مجموعة الأفراد ذوي الاضطرابات العاطفيـة، وتم هـذا التقسيه لكسي يتمكن المعالج النفسي من التعرف أكثر هذا الحقل ولاستخدامـه كوسيلة بصرية ِِّ مجال العلاج النفسي. 